\title{
Diversity and Temporal Dynamics of the Epiphytic Bacterial Communities Associated with the Canopy-Forming Seaweed Cystoseira compressa (Esper) Gerloff and Nizamuddin
}

\author{
Francesco P. Mancuso ${ }^{1,2 *}$, Sofie D'Hondt ${ }^{2}$, Anne Willems ${ }^{3}$, Laura Airoldi ${ }^{1 *}$ and \\ Olivier De Clerck ${ }^{2}$ \\ ${ }^{1}$ Dipartimento di Scienze Biologiche, Geologiche ed Ambientali, Centro Interdipartimentale di Ricerca per le Scienze \\ Ambientali, UO CoNISMa, University of Bologna, Ravenna, Italy, ${ }^{2}$ Phycology Research Group and Center for Molecular \\ Phylogenetics and Evolution, Ghent University, Ghent, Belgium, ${ }^{3}$ Laboratory for Microbiology, Department of Biochemistry \\ and Microbiology, Ghent University, Ghent, Belgium
}

OPEN ACCESS

Edited by:

Olga Lage,

University of Porto, Portugal

Reviewed by:

J. Michael Beman

University of California, Merced, USA

Catherine Maree Burke,

University of Technology Sydney,

Australia

${ }^{*}$ Correspondence:

Francesco P. Mancuso

fscopaolo.mancuso@gmail.com;

Laura Airoldi

laura.airoldi@unibo.it

Specialty section:

This article was submitted to

Aquatic Microbiology,

a section of the journal

Frontiers in Microbiology

Received: 29 November 2015

Accepted: 22 March 2016

Published: 08 April 2016

Citation:

Mancuso FP, D'Hondt S, Willems A,

Airoldi L and De Clerck O (2016)

Diversity and Temporal Dynamics of the Epiphytic Bacterial Communities

Associated with the Canopy-Forming

Seaweed Cystoseira compressa

(Esper) Gerloff and Nizamuddin.

Front. Microbiol. 7:476.

doi: 10.3389/fmicb.2016.00476
Canopy-forming seaweed species of the genus Cystoseira form diverse and productive habitats along temperate rocky coasts of the Mediterranean Sea. Despite numerous studies on the rich macrofauna and flora associated with Cystoseira spp., there is little knowledge about the epiphytic bacteria. We analyzed bacterial populations associated with canopies of Cystoseira compressa, over an annual vegetative cycle (May-October), and their relationships with the bacterial populations in the surrounding seawater, at intertidal rocky shores in Vasto (Chieti-Italy). The bacterial diversity was assessed using Illumina Miseq sequences of V1-V3 hypervariable regions of 16S rRNA gene. C. compressa bacterial community was dominated by sequences of Proteobacteria and Bacteroidetes, Verrucomicrobia, Actinobacteria, and Cyanobacteria especially of the Rhodobacteriaceae, Flavobacteriaceae, Sapropiraceae, Verrucomicrobiaceae, and Phyllobacteriaceae families. Seawater libraries were also dominated by Proteobacteria and Bacteroidetes sequences, especially of the Candidatus Pelagibacter (SAR11) and Rhodobacteriaceae families, but were shown to be clearly distinct from C. compressa libraries with only few species in common between the two habitats. We observed a clear successional pattern in the epiphytic bacteria of $C$. compressa over time. These variations were characterized by gradual addition of OTUs (Verrucomicrobia, Actinobacteria and SR1) to the community over a growing season, indicative of a temporal gradient, rather than a radical reorganization of the bacterial community. Moreover, we also found an increase in abundance over time of Rhodobacteraceae, comprising six potential pathogenic genera, Ruegeria, Nautella, Aquimarina, Loktanella, Saprospira, and Phaeobacter which seemed to be associated to aged thalli of $C$. compressa. These bacteria could have the potential to affect the health and ecology of the algae, suggesting the hypothesis of a possible, but still unexplored, role of the microbial communities in contributing to the extensive ongoing declines of populations of Cystoseira spp. in the Mediterranean Sea.

Keywords: epiphytic bacteria communities, high throughput sequencing, 16S rRNA gene, canopy-forming seaweeds, Fucales, Cystoseira compressa, Mediterranean Sea 


\section{INTRODUCTION}

Canopy seaweeds of the genus Cystoseira C. Agardh (Fucales, Phaeophyceae) are among the most important habitat-forming species in the Mediterranean Sea. With the majority of its species endemic to the Mediterranean Sea (Ribera et al., 1992; Gómez-Garreta et al., 2002; Draisma et al., 2010), Cystoseiradominated vegetations provide food and protection for rich associated communities, comprising other algae, invertebrates and fish (Mineur et al., 2015). In addition Cystoseira stands significantly enhance the structural complexity and productivity of coastal communities from the infralittoral down to the upper circalittoral zone (Giaccone et al., 1994; Bulleri et al., 2002; Falace and Bressan, 2006; Ballesteros et al., 2009).

During the last decades several Cystoseira species have retracted their ranges considerably to the point where several species have been reported to be locally lost (Soltan et al., 2001; Thibaut et al., 2005, 2015; Serio et al., 2006; Mangialajo et al., 2007, 2008; Perkol-Finkel and Airoldi, 2010). The loss of Cystoseira canopies leads to structurally less complex communities most often dominated by low-lying, turf-forming species (Benedetti-Cecchi et al., 2001; Connell et al., 2014) or sea urchin barrens (Agnetta et al., 2015). These shifts are attributable to the interactive effects of different local and global stressors (Asnaghi et al., 2013; Strain et al., 2014, 2015).

The ecological responses of seaweeds to most abiotic and biotic stressors are perceived and transmitted through the algal surface, which represents a highly active interface between the seaweed and the environment. The surface is involved in exchange processes such as the uptake and release of nutrients, waste products and secondary metabolites. Bacteria, which typically form biofilms on the algal surface, are hypothesized to affect the interactions between the seaweeds and the environment by modifying the properties of the external surfaces (Wahl et al., 2012). Bacteria interact with seaweeds, thereby modulating the health, performance and resilience of their hosts. Biofilms can reduce the access of their hosts to light, gases and nutrients and alter the interaction with other fouling epibionts, consumers and pathogens (Goecke et al., 2010; Wahl et al., 2012). The tight relationship between seaweeds and microbiota renders these associations functionally equivalent to a single entity, or a holobiont (Egan et al., 2013). Although a growing number of papers focus on the bacterial communities associated with different seaweeds (e.g., Bengtsson et al., 2012; Wahl et al., 2012; Hollants et al., 2013; Miranda et al., 2013; Campbell et al., 2015), the underlying mechanisms of these associations remain largely unknown.

Recent investigations present a major stride toward documenting the phylogenetic composition of associated bacterial communities and their spatio-temporal dynamics (e.g., Staufenberger et al., 2008; Bengtsson et al., 2010; Burke et al., 2011). Most studies concur that algal-associated bacterial communities are distinct from the surrounding environment and largely host-specific (Lachnit et al., 2009). Nevertheless, bacterial communities display considerable temporal and spatial variation (Campbell et al., 2015; Fuhrman et al., 2015). There is growing evidence that the communities of surface bacteria are highly influenced by the physiology of the host. Bengtsson et al. (2010) demonstrated that assembly and dynamics of the biofilm is correlated with the growth cycle of Laminaria. More recently, observations that microbial communities were more strongly associated with host condition (healthy versus stressed) in the brown alga Ecklonia radiata than with geographical location or environmental variables, highlights that host traits may be a critical determinant of the associated microbial community structure (Marzinelli et al., 2015). Despite these reports, the functional relationships with the host species remain largely an open question. Understanding the dynamics of epiphytic bacteria would allow to explore potentially overlooked mechanisms behind algal responses to environmental or anthropogenic stressors.

We characterized the composition and dynamics of epibiotic bacteria of the canopy-forming seaweed Cystoseira compressa (Esper) Gerloff and Nizamuddin along an intertidal rocky promontory in the southern Adriatic Sea. We used next generation sequencing Illumina Miseq of $16 \mathrm{~S}$ rRNA gene libraries to characterize the diversity (richness, evenness, and community composition) of bacterial communities and describe their successional changes over a vegetative growth season. We also tested whether bacterial communities associated to $C$. compressa were distinct from those found in the surrounding seawater, to explore potential specificities toward the C. compressa host.

\section{MATERIALS AND METHODS}

\section{Study Area and Species}

Cystoseira compressa and associated microbial communities were sampled along the rocky shore at Punta Aderci promontory, Vasto, Italy $\left(42^{\circ} 10^{\prime} 50.3^{\prime \prime} \mathrm{N}, 14^{\circ} 41^{\prime} 15.0^{\prime \prime} \mathrm{E}\right)$ in the central Adriatic Sea (Figure 1A). This promontory, situated in the central sector of Abruzzo coast, is characterized by clay-sand-conglomerate lithotypes (Miccadei et al., 2011), moderate exposure to wave action and an average tidal amplitude of $\approx 30 \mathrm{~cm}$. We sampled populations of $C$. compressa at the sublitoral fringe $(-10 \mathrm{~cm}$ to $+10 \mathrm{~cm}$ relative to Mean Low Water Level; MLWL). Seawater temperature ranges from a minimum of $8^{\circ} \mathrm{C}$ in winter to $27.5^{\circ} \mathrm{C}$ in summer (data from the "Istituto Superiore per la Protezione e Ricerca Ambientale," ISPRA, period 20002013, www.mareografico.it). The underwater rocky substrate is dominated by patches of mussels (Mytilus galloprovincialis), ephemeral algae (Ulva rigida), and perennial stands of $C$. compressa (Figures 1B,C). C. compressa is the only canopyforming alga in this habitat. Like other species of Cystoseira, C. compressa exhibit pronounced seasonal variations in vegetative growth (Gómez-Garreta et al., 2002; Falace et al., 2005). At the study location, new branches develop from a perennial basis in May, providing a fresh substrate for colonizing bacteria. In July, thalli reach their maximum height and physiological activity (Figure 1B) while in late August C. compressa loses most upright branches (Figure 1C). The basal cauloid persists in a quiescent state during the cold winter season. 

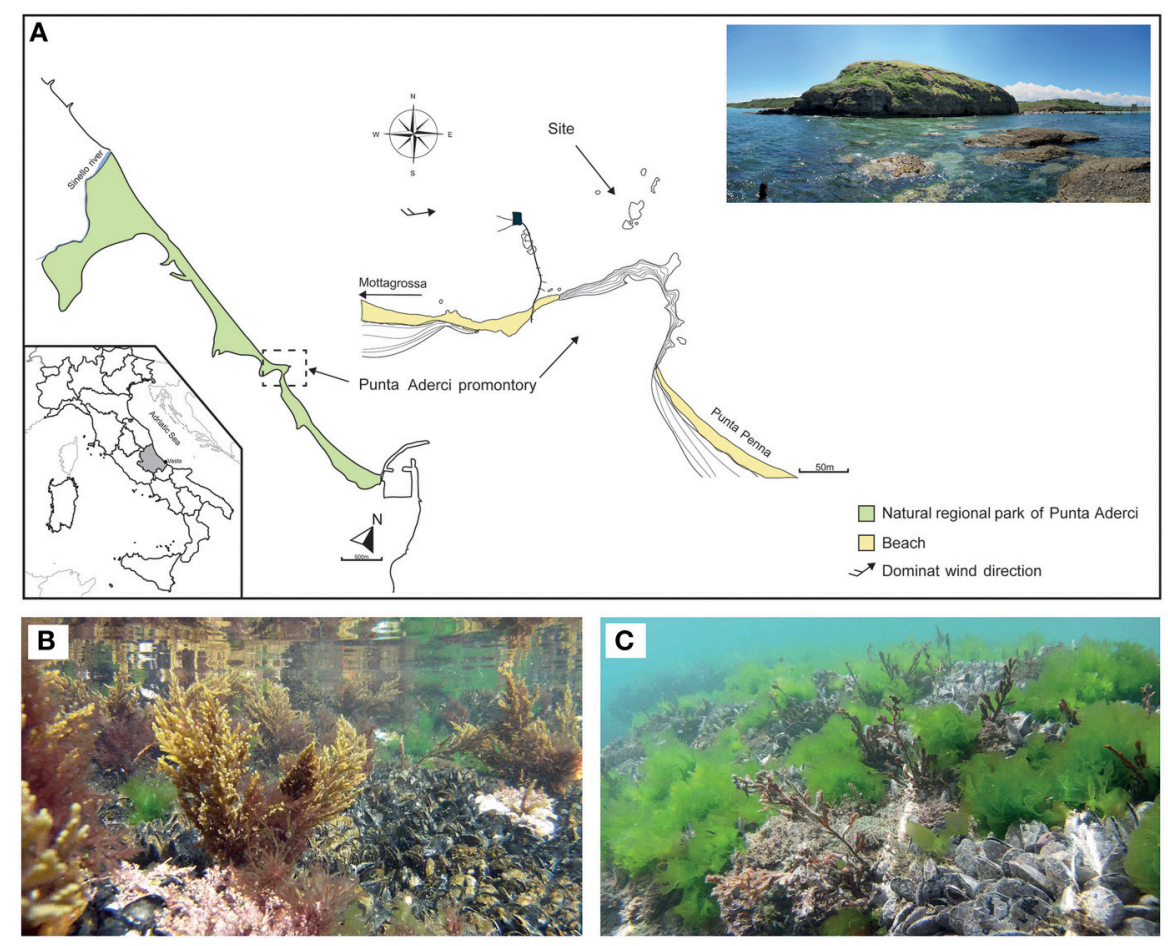

FIGURE 1 | Main physiographic characteristics of the coastal area and sampling site of the Punta Aderci promontory (A). Underwater assemblage characterized by Mytilus galloprovincialis, Ulva rigida and Cystoseira compressa during summer (B) and late summer (C).

\section{Sampling}

Bacterial communities were collected from submerged thalli of C. compressa and the surrounding seawater six times from May to October 2014 during the vegetative growth season (Table S1). Each time, epiphytic bacteria were collected from 3 randomly selected thalli of C. compressa. Sterile cotton swabs on wooden sticks (Aptaca) were used to rub approximately $12 \mathrm{~cm}^{2}$ of surface from the perennial base to the tip of primary branches. Swabs were immediately placed in sterile $1.5 \mathrm{ml}$ Eppendorf tubes. Thalli that were overgrown with epiphytic seaweeds or animals were avoided. To compare the bacterial communities that grow on C. compressa with those present in the surrounding environment, two samples $(n=2)$ of seawater $(500 \mathrm{ml})$ were randomly collected each time using black polyethylene bottles (Kartell). Seawater samples were filtered in the field with an electric vacuum pump, connected to a portable electric generator, first onto $3.0 \mu \mathrm{m}$ pore size cellulose acetate filters (Millipore), to remove most eukaryotes, and then onto $0.2 \mu \mathrm{m}$ pore size cellulose nitrate filters (Sartorius) to retain the bacteria. Samples were transported on ice to the lab and stored at $-80^{\circ} \mathrm{C}$ until DNA extraction.

\section{Characterization of the Bacterial Community}

Microbial DNA was extracted from the swabs using a protocol from Zwart et al. (1998). Briefly, the tip of the swab was placed into a $2 \mathrm{ml}$ tube with $0.5 \mathrm{~g}$ of zirconium beads $(0.1 \mathrm{~mm}$ diameter) to lyse the cells, $0.5 \mathrm{ml} 1 \mathrm{X}$ TE buffer $(10 \mathrm{mM}$
Tris, $\mathrm{pH}$ 8) and $0.5 \mathrm{ml}$ buffered phenol ( $\mathrm{pH} 7-8$ ) were added to the tubes containing the swab tips and the tubes were vigorously shaken $(30 \mathrm{~Hz})$ on a Bead-beater (Retsch) three times for $2 \mathrm{~min}$ with intermittent cooling on ice. The tubes were then centrifuged for $5 \mathrm{~min}$ at $10,000 \mathrm{rpm}$ in a cooled centrifuge $\left(4^{\circ} \mathrm{C}\right)$ and the upper (aqueous) phase was transferred to a new tube and extracted with phenol-chloroformisoamylalcohol (25:24:1). The DNA was then precipitated by adding $1 / 10$ volume of $3 \mathrm{M}$ sodium acetate ( $\mathrm{pH}$ 5) and 2 volumes of $96 \%(\mathrm{v} / \mathrm{v})$ ethanol and incubating overnight at $-20^{\circ} \mathrm{C}$. Subsequently, the DNA was washed with ethanol $70 \%(\mathrm{v} / \mathrm{v})$ and dissolved in 1xTE buffer. The V1-V3 region of the bacterial 16S rRNA gene was amplified using forward pA (AGAGTTTGATCCTGGCTCAG 8-27) (Edwards et al., 1989) and reverse BKL1 1 (GTATTACCGCGGCTGCTGGCA 536516; Cleenwerck et al., 2007) primers. PCR reaction mixes were made using the Faststart High Fidelity PCR system (Roche). The PCR mix consisted of: nuclease-free water; reaction buffer 1x; $0.8 \mathrm{mM}$ of each dNTP; $0.5 \mu \mathrm{M}$ of each primer; $0.02 \mathrm{U}$ Taq (FastStart Taq DNA Polymerase); approximately 30 ng template DNA. PCR conditions were: $94^{\circ} \mathrm{C}$ for $5 \mathrm{~min}, 30$ cycles of $94^{\circ} \mathrm{C}$ for $30 \mathrm{~s}, 50^{\circ} \mathrm{C}$ for $30 \mathrm{~s}, 72^{\circ} \mathrm{C}$ for $30 \mathrm{~s}$, and final elongation at $72^{\circ} \mathrm{C}$ for $7 \mathrm{~min}$. Libraries for Illumina MiSeq v3 $(2 \times 300 \mathrm{bp})$ were constructed using the NexteraXT DNA sample preparation kit with a dual indexing strategy consisting of two 8-base indices. Amplicons obtained from the first PCR were cleaned using Ampure beads. Then we performed a second PCR, with 12 cycles, to attach the adaptors and the indexes on the amplicons obtained 
previously. After a further clean up with Ampure beads and equimolar pooling the samples were sent for sequencing.

The microbial amplicon sequences were processed using the UPARSE pipeline (Edgar, 2013), implemented in the USEARCH package version 8.0.1623 (Edgar, 2010), unless stated otherwise. Paired-end reads with a minimum length overlap of $60 \mathrm{bp}$ were merged, discarding reads with a length shorter or longer than 450 and 530, respectively. Moreover, no gaps were allowed in the alignment of the overlapping region. The reads were quality-filtered by imposing a maximum expected error of 0.5. Samples were pooled and truncated using the trim.seqs function in Mothur (Schloss et al., 2009). After dereplication, singletons were discarded, and sequences were binned into OTUs with a minimum identity of $97 \%$. Chimeric sequences were detected with the UCHIME algorithm (Edgar et al., 2011) using the RDP gold database (training database v9) as a reference. Taxonomy assignment was performed in QIIME 1.9.0 using the Greengenes 16S rRNA gene dataset (13_8_99 release; DeSantis et al., 2006) with RDP classifier method (Wang et al., 2007) and a confidence value of the 0.8 . The sequences were classified from phylum to genus level. After classification chloroplast and mitochondrial sequences were removed from the dataset. Moreover, samples with a library size smaller than 1000 sequences were removed, because samples below this level can suffer from quality issues (Navas-Molina et al., 2013). Finally, to correct for possible contamination during the lab work, OTUs detected in the negative control were removed from the data set. For phylogenetic tree reconstruction, sequences were aligned with Clustal $\Omega$ with default parameters for nucleotide alignment. The phylogenetic tree was reconstructed using the gamma model of sequence evolution (options "-nt -gamma -no2nd -fastest spr 4") in FastTree2 (Price et al., 2010; Hildebrand et al., 2014). Statistical analyses were performed in R software 3.1.2 (R Core Team, 2015) using the "phyloseq" R-package (McMurdie and Holmes, 2013).

Microbial composition was described from phylum to genus level. First, the relative abundance of each OTU within each sample was calculated, then the OTUs were sorted in descending order according to their relative abundance, and the most abundant ones, comprising at least $90 \%$ of the community, were retained. A phylogenetic tree was built and used to show differences between the bacterial communities of $C$. compressa and surrounding seawater. Moreover, the $\log 2$ fold change times based on the OTUs abundance data was calculated to show which OTU contributed more in the differences between habitats.

The original output files of each sample have been submitted to the NCBI sequence read archive under the accession SRX1563424. Sequences of all 3820 OTUs (97\% clustering) have been submitted to GenBank under the accession numbers KU688205-KU692024.

\section{Analysis of Spatial and Temporal Variations}

We characterized the alpha and beta diversity of the bacterial communities collected from two habitats, C. compressa and surrounding seawater, over the six sampling times. To estimate alpha diversity, data sets were rarefied at the number of sequences of the sample with the least sequencing depth. Data were rarefied using the "rarefy_even_depth" function in the "phyloseq" library (we defined a random number seed to 33, $\mathrm{R}$ environment). OTU richness and the Chaol index were calculated using the "estimated_diversity" index in the "phyloseq" library, while Shannon-Wiener index was estimated using the "diversity" function in the "vegan" R-package (Oksanen et al., 2015). Pielou's evenness was calculated as $H / \ln (S)$, where $S$ and $\mathrm{H}$ are the estimated OTU richness and Shannon-Wiener diversity, respectively. For each habitat and each sampling time, we calculated mean values and standards errors for each of these metrics. Differences in alpha diversity parameters between habitats (2 levels, fixed factor) and sampling times (6 levels, random factor, orthogonal to habitat) were statistically tested by performing univariate permutational analyses of variance (PERMANOVA) with PERMANOVA+ (Anderson et al., 2008) for PRIMER v.6 (Clarke and Gorley, 2006). The analysis was based on a Euclidian distance matrix with type III of sum of squares, 9999 permutations, and unrestricted permutation of raw data. PERMANOVA was chosen for univariate analyses because it allows for two-factor designs, considers an interaction term and does not assume a normal distribution of errors.

Spatial and temporal variations of the bacterial communities structure were displayed by unconstrained ordination plots using the principal coordinate analysis (PCoA), based on a Bray-Curtis distance matrix calculated from the square-root transformed OTU abundance data. Differences between habitats and sampling times of the bacterial communities were statistically tested by using a multivariate PERMANOVA. The PERMANOVA analysis was based on a Bray-Curtis similarity matrix with type III of sum of squares, 9999 permutations and unrestricted permutation of raw data. SIMPER analysis was performed in PRIMER v.6 (Clarke and Gorley, 2006) to identify those OTUs that most characterized the epiphytic bacteria community composition of C. compressa at each time or that mostly contributed to the differences observed. Cut-off value was restricted to $60 \%$. To explore how different OTUs contributed to the diversity patterns, bubble plots of the abundances of the main correlated OTUs were plotted on the PCoA graph.

\section{RESULTS}

Targeting the hypervariable V1-V3 region of the 16S rRNA, a total of 15,799,968 paired-end raw reads were obtained using the Illumina Miseq v.3 platform. After quality filtering and discarding singletons, chimeras and chloroplast and mitochondrial sequences, our dataset contained 1,289,599 sequences with an average length of $483 \pm 5$ bp. The average number of reads was 44,469 per library $(S D=18,999$; $\min =$ 8,727 ; $\max =75,903$ ) while the total OTU richness was 3820 at the $97 \%$ OTU definition (see Tables S1, S2 for more details). Classification of OTUs against the Greengenes database resulted in 56.9 and $16.2 \%$ of the OTUs being classified at family and genus levels, respectively. Classification success increased from 71.9 to $100 \%$ with higher taxonomic levels (Figure S1). Rarefaction curves showed saturation for most of the samples, indicative of a good coverage of diversity (Figure 2). 


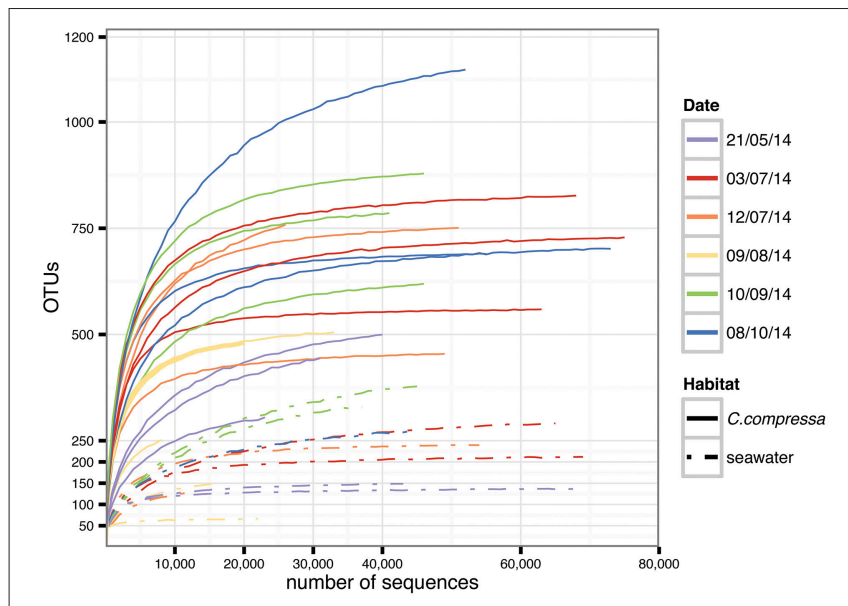

FIGURE 2 | Rarefaction curves generated for each sample. Solid and dot-dash lines refer to Cystoseira compressa and seawater samples, respectively. Colors represent different time points.

\section{Bacterial Diversity of C. compressa and Surrounding Seawater}

Cystoseira-associated bacterial diversity was significantly higher compared to the surrounding seawater at all sampling times (Figures 3A,B, Table S3). Likewise, the Shannon index was always higher in bacterial communities associated to Cystoseira than in the surrounding seawater (Figure 3C). Bacterial evenness was generally high both on Cystoseira and in the surrounding seawater, with Pielou's evenness index slightly higher on Cystoseira samples (Figure 3D).

Phylogenetic characterization identified 33 phyla of Bacteria: 13 of these (Proteobacteria, Bacteroidetes, Verrucomicrobia, Actinobacteria, SR1, OD1, Thermi, GN02, Chloroflexi, Planctomycetes, TM7, Fusobacteria, Cyanobacteria), together with the OTUs that could not be classified at phylum level, comprised more than $90 \%$ of the diversity in the dataset. Proteobacteria, Bacteroidetes, Actinobacteria, Verrucomicrobia, and Cyanobacteria were by far the most abundant taxa, accounting for $69.7,9.7,2.9,2.7$, and $2.2 \%$ of the diversity, respectively (Figure 4A and Table S4). At the family level, most sequences of the epiphytic bacteria on C. compressa were classified as Rhodobacteraceae (34.7\%), Flavobacteriaceae (6.6\%), Saprospiraceae, and Verrucomicrobiaceae (5.2\% each), while the seawater samples mainly comprised representatives of Pelagibacteraceae (40.2\%) and Rhodobacteraceae (27.6\%). About $15-16 \%$ of the OTUs, however, remained unclassified at family level in both habitats (Figure 4B and Table S5). At genus level only the $28.6 \%$ of the OTUs were classified. C. compressa harbored Loktanella (8.8\%), Pseudoruegeria (3.6\%) (family Rhodobacteraceae), and Haloferula (2.6\%) (family Verrucomicrobiaceae), while seawater samples showed an important presence of Oceanibulbus (5.1\%) (family Rhodobacteraceae) and Erythrobacter (1.2\%) (family Erythrobacteraceae). However, the high percentage of unclassified OTUs at genus level does not allow providing detailed information of the two habitats at that level (Figure 4C).
Of the 13 phyla mentioned above, Chloroflexi, and TM7 were exclusively found associated to $C$. compressa. Overall, $C$. compressa hosted a much greater number of exclusive OTUs (121) than seawater (19) (Figure 5).

\section{Successional Changes in Epibacterial Diversity on C. compressa and Surrounding Seawater}

The PERMANOVA revealed significant differences of bacterial community between $C$. compressa and surrounding seawater in all terms [Table S6; Habitats, pseudo- $\mathrm{F}_{(d f=1,17)}=16.459, p$ $<0.05$; Date, pseudo- $\mathrm{F}_{(d f=5,17)}=2.0629 p<0.05$; Habitats $\times$ Date, pseudo- $\left.\mathrm{F}_{(d f=5,17)}=1.9768, p<0.05\right]$. The PCoA ordination displayed these differences (Figure 6). The proportion of variance accounted for by the first two axes was $70.4 \%$. This high value makes us confident that our interpretation of the first pair of axes extracts most relevant information from the data. The first axis accounted for the major part of the variance (61.9\%) and highlights the big differences between seawater on the one hand and the thallus surface on the other hand (Figure 6). The second axis accounted the $8.5 \%$ of the total variation and reflects the time series. This axis revealed a clear successional pattern of the epiphytic bacterial community of C. compressa from May to October that was not observed in the seawater samples (Figure 6). The successional pattern in C. compressa was also reflected in a continuous increase of OTUs richness that conversely was not observed in the surrounding seawater (Figure 7). Of the 3227 OTUs, a subset of 400 represented $90 \%$ of the diversity of the epiphytic bacteria on C. compressa. Of these, 173 were present in all samples. SIMPER analysis revealed a high number of OTUs contributing both to the similarity between samples at the same time point as well as to differences between sampling times. Between May ( $\mathrm{t} 1$ ) and October ( $\mathrm{t} 6$ ) 102 OTUs contributed to $66.9 \%$ of dissimilarity (Table S7A). Of these, 32 OTUs showed higher Pearson correlation $(>0.6)$ in their abundance over time with some OTUs that tend to decrease or increase from May to October (Figure 8A). In October we observed an increase of OTUs belonging to Rhodobacteraceae. In particular the genera Ruegeria, Nautella, Aquimarina, Loktanella, Saprospira, and Phaeobacter increased in abundance with the natural degradation of the thalli of C. compressa (Figure S2).

With respect to the seawater, of a total of 1085 OTUs, 100 represented $98 \%$ of the bacterial diversity. SIMPER analysis revealed that 27 OTUs contributed to the $32.6 \%$ of dissimilarity between May (t1) and October (t6) (Table S7B). Of these 11 OTUs decreased in their abundance from May to October (cor. $>0.6$ ) (Figure 8B). Two of these were identified at genus level as Octadecabacter (family Rhodobacteraceae) and Flavobacterium (family Flavobacteriaceae) (Table S7B). Finally, of the higher correlated OTUs found in the two habitats from May to October there were not shared taxa.

\section{DISCUSSION}

We describe for the first time the bacterial communities of the canopy-forming alga Cystoseira compressa and surrounding 

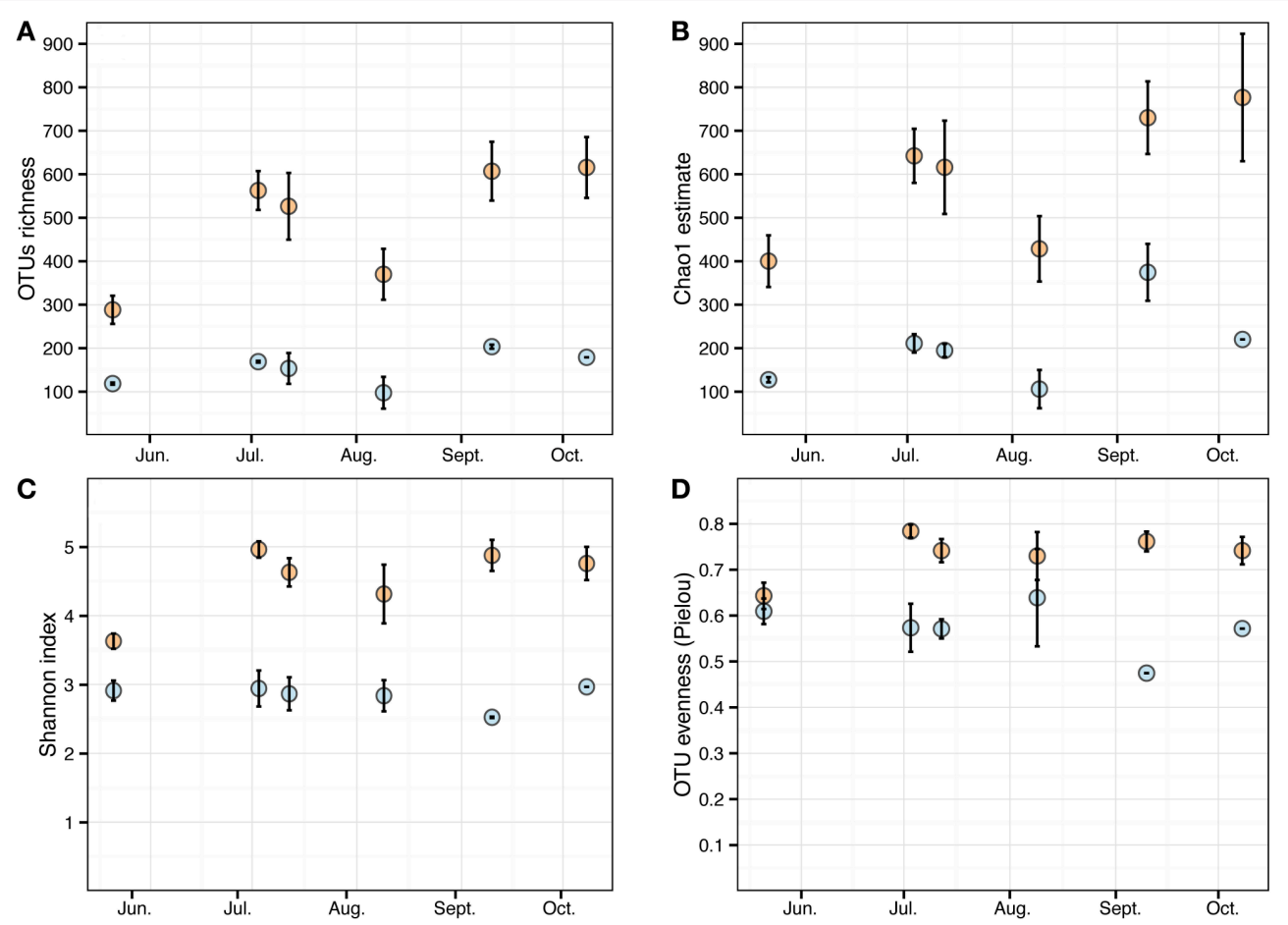

FIGURE 3 | Alpha diversity measures of the microbial communities associated to C. compressa (orange) and surrounding seawater (blue) across seasons. Observed OTUs (A), Chao1 species richness estimates (B), Shannon diversity H' (C), and Pielou's evenness index (D). Values are means \pm standard error $(n=3-2)$.
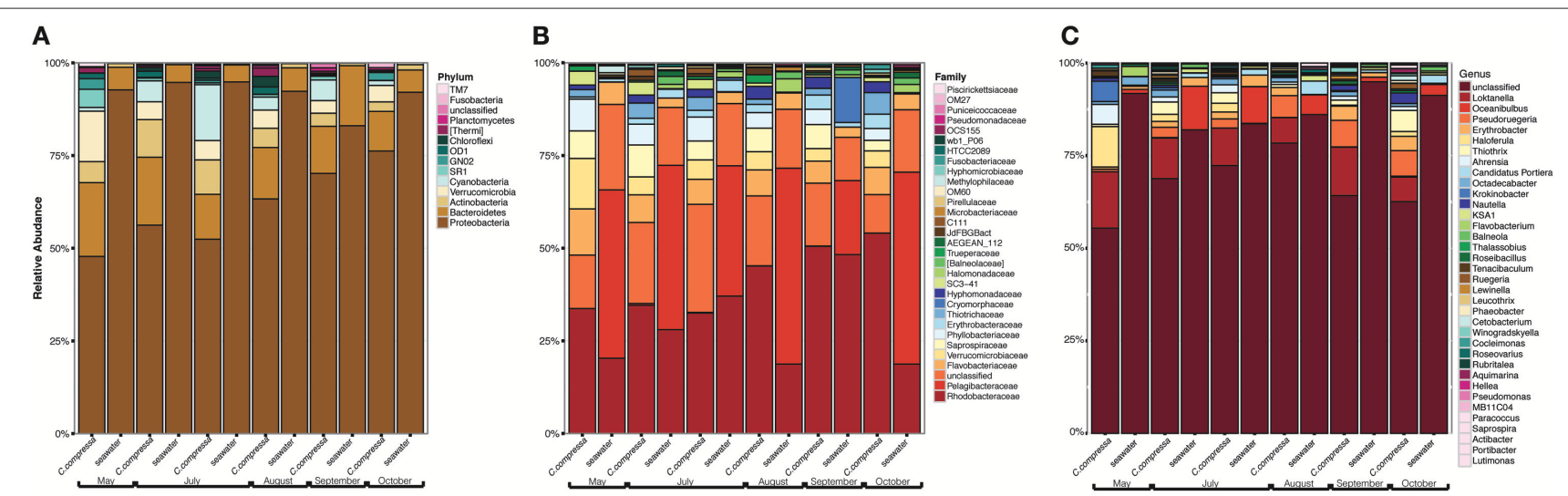

FIGURE 4 | Pattern of the bacterial communities of C. compressa and surrounding seawater across seasons. Data reported are the relative abundance of the top 300 OTUs accounting for the $92 \%$ of the data set at phylum (A), family (B), and genus (C) levels.

seawater using next generation sequencing data. The most abundant groups of bacteria in both habitats belonged to Proteobacteria and Bacteroidetes. Consistent with other studies (Staufenberger et al., 2008; Lachnit et al., 2009; Bengtsson et al., 2010; Burke et al., 2011), we found a clear difference between the bacterial communities of $C$. compressa and the surrounding seawater. The bacterial community of seawater remains more stable compared to that on $C$. compressa, that showed a clear successional pattern associated to aging thalli.
These variations were characterized by gradual addition of OTUs (Verrucomicrobia, Actinobacteria and SR1) to the epiphytic community, suggesting a clear successional trend. We also found an increase in abundance of potential microbial pathogens associated to older thalli of $C$. compressa.

Even though biofilm-forming bacteria need to be recruited from the surrounding environment, the large differences between seaweed-associated bacteria and those of the surrounding water column are indicative of a selection process whereby the seaweed, 


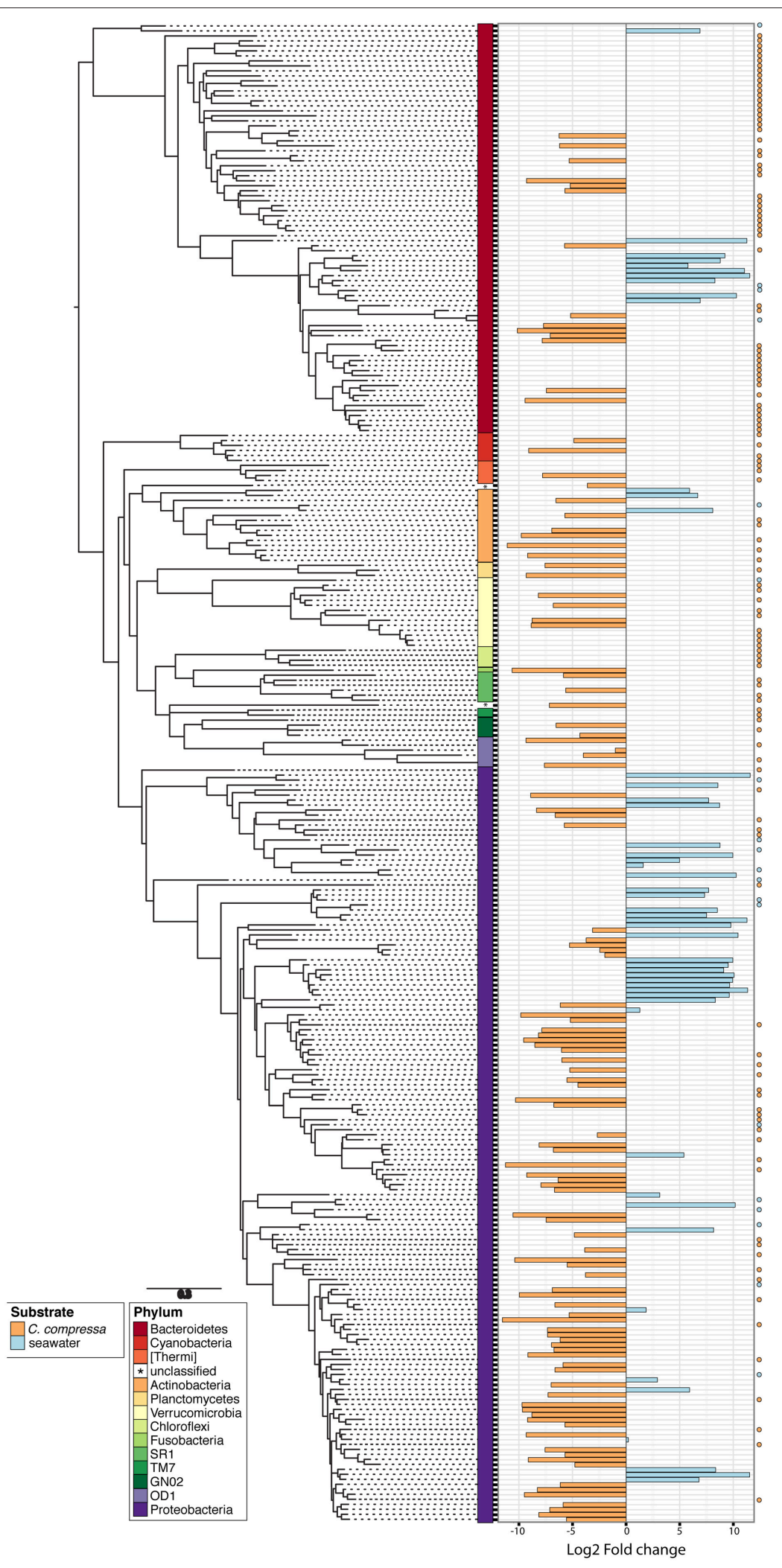

FIGURE 5 | Phylogenetic tree of the dominant OTUs $(n=300)$ in bacterial communities associated with $C$. compressa and the surrounding seawater. The color strips denote phylum-level classification. Bar plot shows the Log2 fold change times based on the OTUs abundance on C. compressa (orange) and in seawater (blue). Dot points show exclusive species for each habitat. 


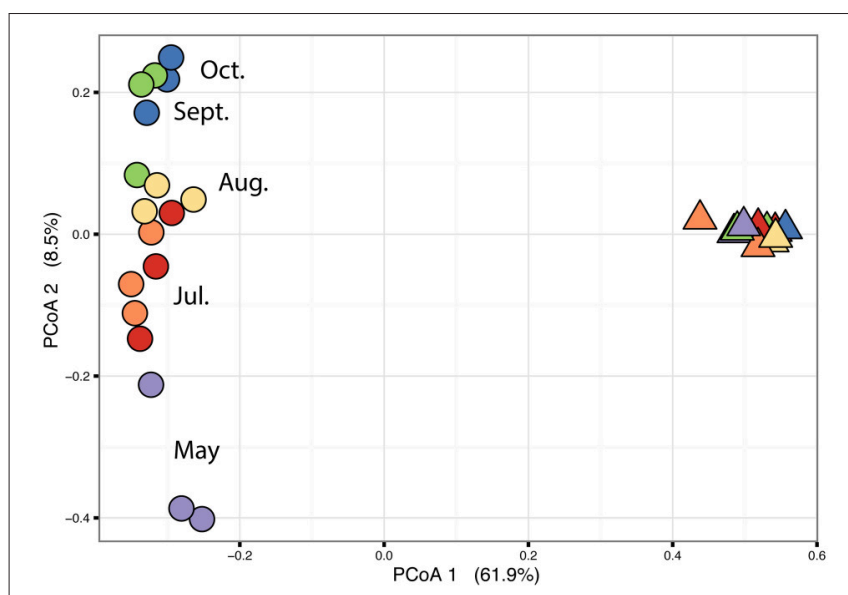

FIGURE 6 | Principal coordinate analysis plot (PCoA) based on a Bray-Curtis distance matrix calculated from the square-root transformed OTU abundance data of the bacterial community of $C$. compressa and surrounding seawater across times. Violet, red, orange, yellow, green, and blue points represent the following sample times respectively: 21-05-14, 03-07-14, 12-07-14, 09-08-14, 10-09-14, and 08-10-14

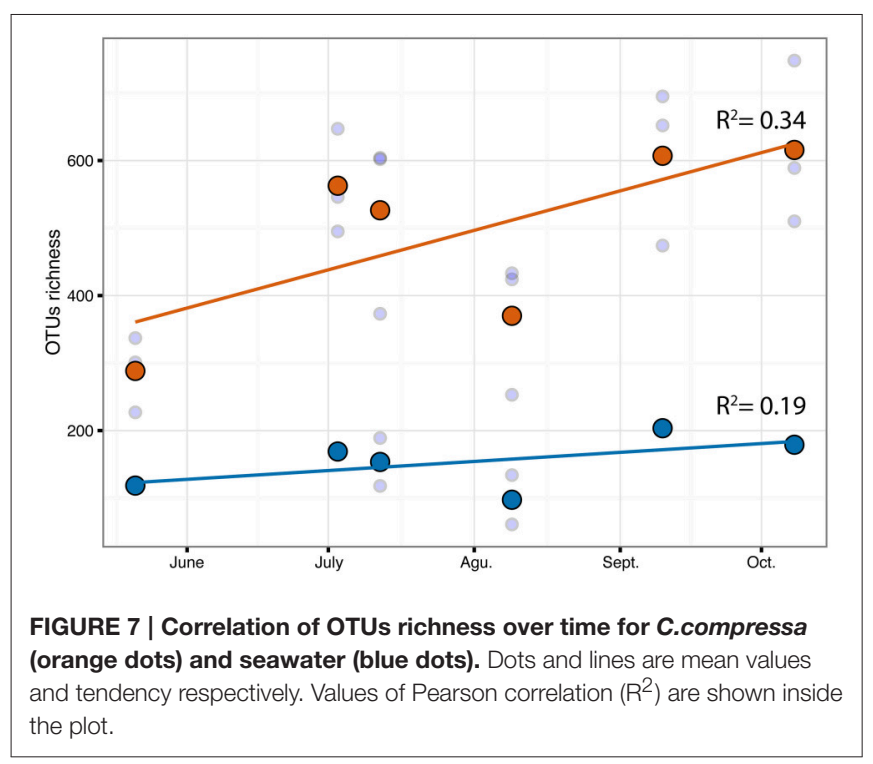

the bacteria or a combination of both have the capacity to modulate the recruitment of the biofilm. Our results support the idea of the presence of generalist epiphytes common to all or many macroalgae (Egan et al., 2013). Alphaproteobacteria, Bacteroidetes, Cyanobacteria, Verrucomicrobia were abundantly found on other brown algae such as Fucus vesiculosus (Lachnit et al., 2011), Saccharina latissima (Staufenberger et al., 2008) as well as green algae (Burke et al., 2011). Of the four most abundant OTUs detected in this study two were identified as Loktanella and Pseudoruegeria. Different species of Loktanella have been found on Fucus vesiculosus (Lachnit et al., 2011; Stratil et al., 2013), Ulva australis (Burke et al., 2011) and other macroalgal species (Egan et al., 2013; Hollants et al., 2013; Miranda et al., 2013). The presence of these genera can be related to their capacity to utilize organic carbon sources released from the seaweeds (Bengtsson et al., 2011). The latter provide substrate but also nutrients and trigger chemotactic behavior of bacteria that are highly adaptive and capable of rapid metabolization of algal exudates (Goecke et al., 2010; Wahl et al., 2012).

During spring ( $\sim$ May), when new branches of C. compressa provide a fresh substrate for colonizing bacteria, the epiphytic bacterial community was characterized by lower OTU richness, evenness and Shannon index. The low evenness was due a low number of OTUs and the dominance of 8 OTUs mainly belonging to the Proteobacteria that make up nearly $50 \%$ of the sequences in spring. We hypothesize that the lower OTU richness found in spring is a consequence of a natural colonization process of the microbial biofilm. In July, thalli of C. compressa at the study site reach their maximum dimension and physiological activity. Even though not directly observed in C. compressa species, the increase of seawater temperature induces a high photosynthetic activity and concomitant exudation rates of carbohydrates (Abdullah and Fredriksen, 2004; Wada et al., 2007) that can be beneficial for heterotrophic bacteria (Bengtsson et al., 2011, 2012). Hence, in July the growth of the epiphytic bacteria on C. compressa leads to an increase of OTUs richness and higher evenness values indicative of the presence of a well-structured community. The shift of the epiphytic community from May to July is also reflected by the increase of reads belonging to Cyanobacteria. This aspect was also observed on Fucus vesiculosus (Lachnit et al., 2011). In August, when C. compressa sheds the majority of upright annual axes, the epiphytic community of $C$. compressa seems to undergo important changes. In fact we observed a drastic decrease to half of OTU richness compared to July. However, we did not observe the same reduction on the evenness values. In September-October the OTUs richness and evenness seems to recover to levels observed in July. The higher OTUs richness may result from the decrease of the seaweed's physiological activity and antimicrobial activity whereby the quiescent status of the alga would explain the increase in abundances of Rhodobacteraceae and in particular of different genera such as Ruegeria, Nautella, Aquimarina, Loktanella, Saprospira, and Phaeobacter as already observed in bleached parts of the red seaweed Delisea pulchra (Case et al., 2011; Fernandes et al., 2011, 2012; Zozaya-Valdes et al., 2015).

Extensive loss of Cystoseira species, including C. compressa, has been reported in recent years, which has been attributed to the interacting effects of local and global stressors (Perkol-Finkel and Airoldi, 2010; Strain et al., 2015). The exact mechanisms behind these losses have not been fully understood yet, and ongoing experiments have led to the hypothesis of a possible, but up till now unexplored, role of the microbial communities. In fact, the tight interaction between bacteria and their host suggests that the epiphytic microbial community can play an important role in the resilience capability of their host. Moreover, the metabolic capability of bacteria to grow and divide very rapidly may result in bacteria responding faster to external stressors compared their host. In this perspective bacteria should be a potential first indicator of environmental or anthropogenic stressors. Our results provide an important base-knowledge 
A
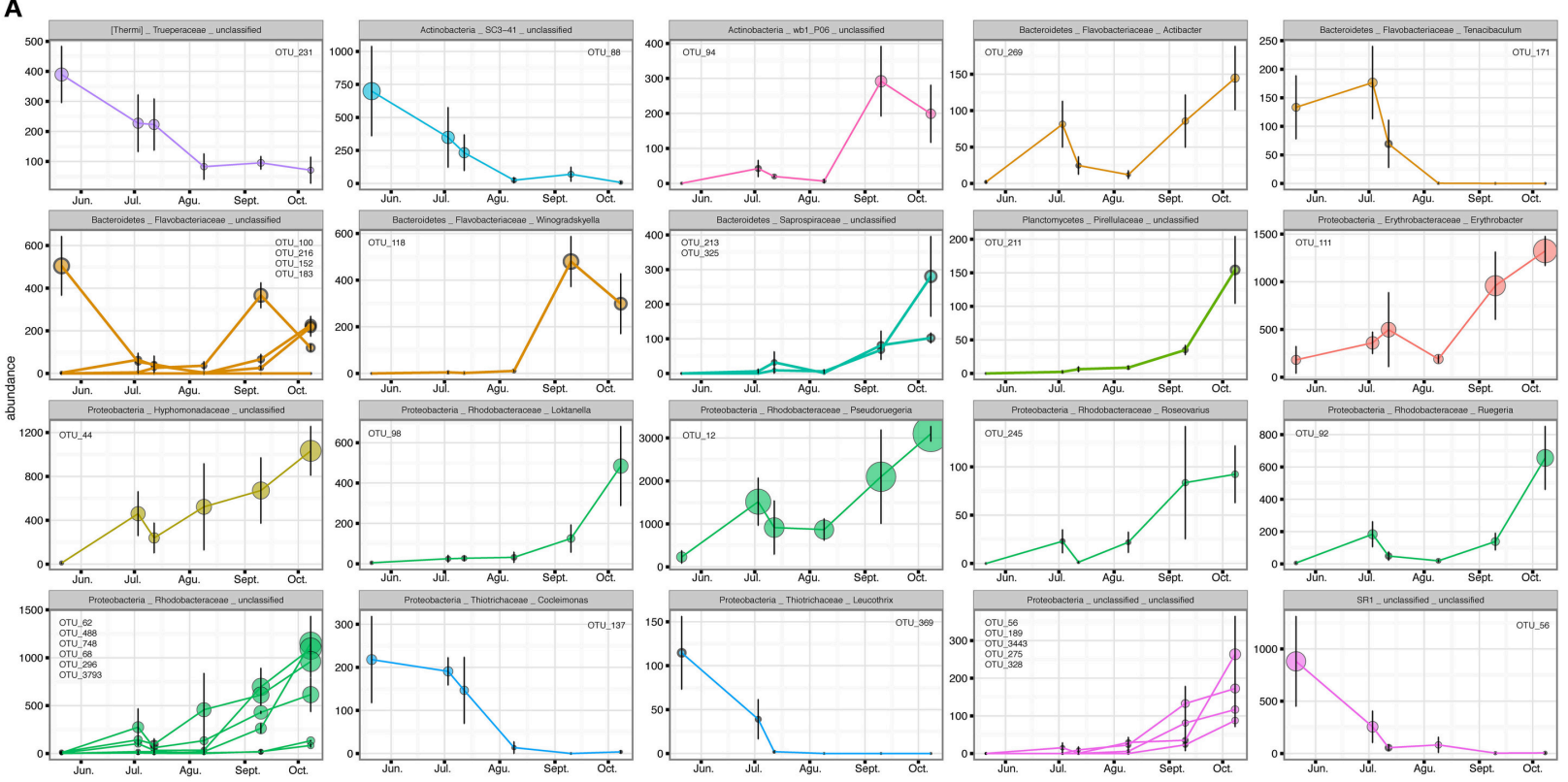

B
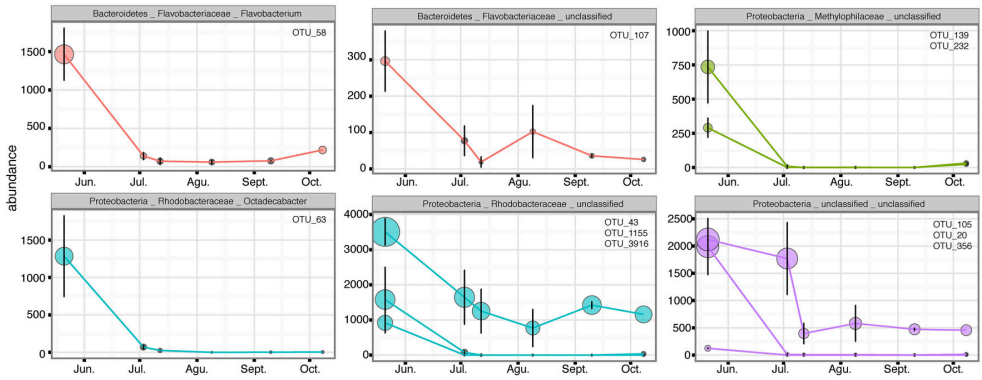

FIGURE 8 | OTUs with higher Pearson correlation $(>0.6)$ in their abundance over time, contributing to the differences in the epiphytic bacteria of $C$. compressa (A) and surrounding seawater (B) between time 1 and $\mathbf{6}$ (May-October). The OTUs are grouped by phylum, family and genus. OTUs number are reported inside each graph.

as first step to analyze the possible mechanisms by which Cystoseira interacts with surface bacteria. In fact, understanding the temporal dynamics of epiphytic bacteria under natural conditions can help to identify possible modifications of the biofilm due to external factors of stress. Then experiments should be performed to explore the response of the holobiont under the combined effects of local and global stressors known to be major causes of the loss of $C$. compressa. Particular consideration should be given to those taxa, such as Ruegeria, Nautella, Aquimarina, Loktanella, Saprospira, and Phaeobacter, that tend to be more present during the natural degradation of C. compressa, to observe if stressors can directly increase the abundance of these taxa or alternatively affect the antimicrobial activities of the seaweed with consequent rise of deleterious taxa.

\section{AUTHOR CONTRIBUTIONS}

FM, LA, OD, and AW designed the work. FM Acquisition, analysis and interpretation of data for the work. SD assisted FM with the molecular lab work. All authors contributed to the writing of the paper.

\section{ACKNOWLEDGMENTS}

We thank Elena Piccioni and Roberto Buonomo for the assistance during the sampling. This study was funded in part by the Italian project TETRIS (Observing, modeling and TEsting synergies and TRade-offs for the adaptive management of multiple Impacts in coastal Systems).

\section{SUPPLEMENTARY MATERIAL}

The Supplementary Material for this article can be found online at: http://journal.frontiersin.org/article/10.3389/fmicb. 2016.00476 


\section{REFERENCES}

Abdullah, M. I., and Fredriksen, S. (2004). Production, respiration and exudation of dissolved organic matter by the kelp Laminaria hyperborea along the west coast of Norway. J. Mar. Biol. Assoc. UK 84, 887-894. doi: 10.1017/S002531540401015Xh

Agnetta, D., Badalamenti, F., Ceccherelli, G., Di Trapani, F., Bonaviri, C., and Gianguzza, P. (2015). Role of two co-occurring Mediterranean sea urchins in the formation of barren from Cystoseira canopy. Estuar. Coast. Shelf Sci. 152, 73-77. doi: 10.1016/j.ecss.2014.11.023

Anderson, M. J., Gorley, R. N., and Clarke, K. R. (2008). PERMANOVA+ for PRIMER: Guide to Software and Statistical Methods, PRIMER-E. Plymouth: PRIMER-E.

Asnaghi, V., Chiantore, M., Mangialajo, L., Gazeau, F., Francour, P., Alliouane, S., et al. (2013). Cascading effects of ocean acidification in a rocky subtidal community. PLoS ONE 8:e61978. doi: 10.1371/journal.pone.0061978

Ballesteros, E., Garrabou, J., Hereu, B., Zabala, M., Cebrian, E., and Sala, E. (2009). Deep-water stands of Cystoseira zosteroides C. Agardh (Fucales, Ochrophyta) in the Northwestern Mediterranean: insights into assemblage structure and population dynamics. Estuar. Coast. Shelf Sci. 82, 477-484. doi: 10.1016/j.ecss.2009.02.013

Benedetti-Cecchi, L., Pannacciulli, F., Bulleri, F., Moschella, P., Airoldi, L., Relini, G., et al. (2001). Predicting the consequences of anthropogenic disturbance: large-scale effects of loss of canopy algae on rocky shores. Mar. Ecol. Prog. Ser. 214, 137-150. doi: 10.3354/meps214137

Bengtsson, M. M., Sjøtun, K., and Øvreås, L. (2010). Seasonal dynamics of bacterial biofilms on the kelp Laminaria hyperborea. Aquat. Microb. Ecol. 60, 71-83. doi: 10.3354/ame01409

Bengtsson, M. M., Sjøtun, K., Lanzén, A., and Øvreås, L. (2012). Bacterial diversity in relation to secondary production and succession on surfaces of the kelp Laminaria hyperborea. ISME J. 2188-2198. doi: 10.1038/ismej.2012.67

Bengtsson, M. M., Sjøtun, K., Storesund, J. E., and Øvreås, L. (2011). Utilization of kelp-derived carbon sources by kelp surface-associated bacteria. Aquat. Microb. Ecol. 62, 191-199. doi: 10.3354/ame01477

Bulleri, F., Benedetti-Cecchi, L., Acunto, S., Cinelli, F., and Hawkins, S. J. (2002). The influence of canopy algae on vertical patterns of distribution of low-shore assemblages on rocky coasts in the northwest Mediterranean. J. Exp. Mar. Bio. Ecol. 267, 89-106. doi: 10.1016/S0022-0981(01)00361-6

Burke, C., Thomas, T., Lewis, M., Steinberg, P., and Kjelleberg, S. (2011). Composition, uniqueness and variability of the epiphytic bacterial community of the green alga Ulva australis. ISME J. 5, 590-600. doi: 10.1038/ismej. 2010.164

Campbell, A. H., Marzinelli, E. M., Gelber, J., and Steinberg, P. D. (2015). Spatial variability of microbial assemblages associated with a dominant habitatforming seaweed. Front. Microbiol. 6:230. doi: 10.3389/fmicb.2015.00230

Case, R. J., Longford, S. R., Campbell, A. H., Low, A., Tujula, N., Steinberg, P. D., et al. (2011). Temperature induced bacterial virulence and bleaching disease in a chemically defended marine macroalga. Environ. Microbiol. 13, 529-537. doi: $10.1111 / j .1462-2920.2010 .02356 . x$

Clarke, K. R., and Gorley, R. N. (2006). Primer v6: User Manual/Tutorial. Plymouth: PRIMER-E.

Cleenwerck, I., Camu, N., Engelbeen, K., De Winter, T., Vandemeulebroecke, K., De Vos, P., et al. (2007). Acetobacter ghanensis sp. nov., a novel acetic acid bacterium isolated from traditional heap fermentations of Ghanaian cocoa beans. Int. J. Syst. Evol. Microbiol. 57, 1647-1652. doi: 10.1099/ijs.0.64840-0

Connell, S. D., Foster, M. S., and Airoldi, L. (2014). What are algal turfs? Towards a better description of turfs. Mar. Ecol. Prog. Ser. 495, 299-307. doi: 10.3354/meps 10513

DeSantis, T. Z., Hugenholtz, P., Larsen, N., Rojas, M., Brodie, E. L., Keller, K., et al. (2006). Greengenes, a chimera-checked 16S rRNA gene database and workbench compatible with ARB. Appl. Environ. Microbiol. 72, 5069-5072. doi: 10.1128/AEM.03006-05

Draisma, S. G. A., Ballesteros, E., Rousseau, F., and Thibaut, T. (2010). DNA sequence data demonstrate the polyphyly of the genus cystoseira and other sargassaceae genera (phaeophyceae). J. Phycol. 46, 1329-1345. doi: 10.1111/j.1529-8817.2010.00891.x

Edgar, R. C. (2010). Search and clustering orders of magnitude faster than BLAST. Bioinformatics 26, 2460-2461. doi: 10.1093/bioinformatics/btq461
Edgar, R. C. (2013). UPARSE: highly accurate OTU sequences from microbial amplicon reads. Nat. Methods 10, 996-998. doi: 10.1038/nmeth.2604

Edgar, R. C., Haas, B. J., Clemente, J. C., Quince, C., and Knight, R. (2011) UCHIME improves sensitivity and speed of chimera detection. Bioinformatics 27, 2194-2200. doi: 10.1093/bioinformatics/btr381

Edwards, U., Rogall, T., Blöcker, H., Emde, M., and Böttger, E. C. (1989). Isolation and direct complete nucleotide determination of entire genes. Characterization of a gene coding for 16 S ribosomal RNA. Nucleic Acids Res. 17, 7843-7853. doi: 10.1093/nar/17.19.7843

Egan, S., Harder, T., Burke, C., Steinberg, P., Kjelleberg, S., and Thomas, T. (2013). The seaweed holobiont: Understanding seaweed-bacteria interactions. FEMS Microbiol. Rev. 37, 462-476. doi: 10.1111/1574-6976.12011

Falace, A., and Bressan, G. (2006). Seasonal Variations of Cystoseira barbata (Stackhouse) C. Agardh Frond Architecture. Hydrobiologia 555, 193-206. doi: 10.1007/s10750-005-1116-2

Falace, A., Zanelli, E., and Bressan, G. (2005). Morphological and reproductive phenology of Cystoseira compressa (Esper) Gerloff \& Nizamuddin (Fucales, Fucophyceae) in the Gulf of Trieste (North Adriatic). Ann. Ser. Hist. Nat. 15, 71-78.

Fernandes, N., Case, R. J., Longford, S. R., Seyedsayamdost, M. R., Steinberg, P. D., Kjelleberg, S., et al. (2011). Genomes and virulence factors of novel bacterial pathogens causing bleaching disease in the marine red alga delisea pulchra. PLoS ONE 6:e27387. doi: 10.1371/journal.pone.0027387

Fernandes, N., Steinberg, P., Rusch, D., Kjelleberg, S., and Thomas, T. (2012). Community structure and functional gene profile of bacteria on healthy and diseased thalli of the red seaweed delisea pulchra. PLOS ONE 7:e50854. doi: 10.1371/journal.pone.0050854

Fuhrman, J. A., Cram, J. A., and Needham, D. M. (2015). Marine microbial community dynamics and their ecological interpretation. Nat. Rev. Microbiol. 13, 133-146. doi: 10.1038/nrmicro3417

Giaccone, G., Alongi, G., Pizzuto, F., and Cossu, A. V. L. (1994). La Vegetazione marina bentonica fotofila del Mediterraneo: 2.: infralitorale e Circalitorale: proposte di aggiornamento. Boll. Dell'accademia Gioenia di Sci. Nat. 27, 111-157. Available online at: http://eprints.uniss.it/6873/1/Giaccone _G_Vegetazione_marina_bentonica_fotofila.pdf

Goecke, F., Labes, A., Wiese, J., and Imhoff, J. F. (2010). Review chemical interactions between marine macroalgae and bacteria. Mar. Ecol. Prog. Ser. 409, 267-300. doi: 10.3354/meps08607

Gómez-Garreta, A., Barceló, M. C., Gallardo, T., Perez-Ruzafa, I. M., Ribera, M. A., and Rull, J. (2002). Flora Phycologica Iberica. Vol. 1. Fucales. Murcia: Universidad de Murcia.

Hildebrand, F., Tadeo, R., Voigt, A. Y., Bork, P., and Raes, J. (2014). LotuS: an efficient and user-friendly OTU processing pipeline. Microbiome 2, 1-7. doi: 10.1186/2049-2618-2-30

Hollants, J., Leliaert, F., De Clerck, O., and Willems, A. (2013). What we can learn from sushi: A review on seaweed-bacterial associations. FEMS Microbiol. Ecol. 83, 1-16. doi: 10.1111/j.1574-6941.2012.01446.x

Lachnit, T., Blümel, M., Imhoff, J. F., and Wahl, M. (2009). Specific epibacterial communities on macroalgae: Phylogeny matters more than habitat. Aquat. Biol. 5, 181-186. doi: 10.3354/ab00149

Lachnit, T., Meske, D., Wahl, M., Harder, T., and Schmitz, R. (2011). Epibacterial community patterns on marine macroalgae are host-specific but temporally variable. Environ. Microbiol. 13, 655-665. doi: 10.1111/j.14622920.2010.02371.x

Mangialajo, L., Chiantore, M., and Cattaneo-Vietti, R. (2008). Loss of fucoid algae along a gradient of urbanisation, and structure of benthic assemblages. Mar. Ecol. Prog. Ser. 358, 63-74. doi: 10.3354/meps07400

Mangialajo, L., Ruggieri, N., Asnaghi, V., Chiantore, M., Povero, P., and CattaneoVietti, R. (2007). Ecological status in the Ligurian Sea: the effect of coastline urbanisation and the importance of proper reference sites. Mar. Pollut. Bull. 55, 30-41. doi: 10.1016/j.marpolbul.2006.08.022

Marzinelli, E. M., Campbell, A. H., Zozaya Valdes, E., Vergés, A., Nielsen, S. Wernberg, T., et al. (2015). Continental-scale variation in seaweed hostassociated bacterial communities is a function of host condition, not geography. Environ. Microbiol. 17, 4078-4088. doi: 10.1111/1462-2920.12972

McMurdie, P. J., and Holmes, S. (2013). Phyloseq: an R Package for reproducible interactive analysis and graphics of microbiome census data. PLoS ONE 8:e61217. doi: 10.1371/journal.pone.0061217 
Miccadei, E., Mascioli, F., Piacentini, T., and Ricci, F. (2011). Geomorphological features of coastal dunes along the central adriatic coast (Abruzzo, Italy). J. Coast. Res. 277, 1122-1136. doi: 10.2112/JCOASTRES-D-10-00161.1

Mineur, F., Arenas, F., Assis, J., Davies, A. J., Engelen, A. H., Fernandes, F., et al. (2015). European seaweeds under pressure: Consequences for communities and ecosystem functioning. J. Sea Res. 98, 91-108. doi: 10.1016/j.seares.2014.11.004

Miranda, L. N., Hutchison, K., Grossman, A. R., and Brawley, S. H. (2013). Diversity and abundance of the bacterial community of the red macroalga porphyra umbilicalis: did bacterial farmers produce macroalgae? PLoS ONE 8:e58269. doi: 10.1371/journal.pone.0058269

Navas-Molina, J. A., Peralta-Sánchez, J. M., González, A., McMurdie, P. J., Vázquez-Baeza, Y., Xu, Z., et al. (2013). “Advancing our understanding of the human microbiome using QIIME," in Methods in Enzymology (Elsevier Inc.), 371-444. doi: 10.1016/B978-0-12-407863-5.00019-8

Oksanen, A. J., Blanchet, F. G., Kindt, R., Legendre, P., Minchin, P. R., Hara, R. B. O., et al. (2015). Community Ecology Package. Vegan: R package version 2.3-0. Available online at: http://CRAN.R-project.org/package=vegan

Perkol-Finkel, S., and Airoldi, L. (2010). Loss and recovery potential of marine habitats: an experimental study of factors maintaining resilience in subtidal algal forests at the Adriatic Sea. PLOS ONE 5:e10791. doi: 10.1371/journal.pone.0010791

Price, M. N., Dehal, P. S., and Arkin, A. P. (2010). FastTree 2-approximately maximum-likelihood trees for large alignments. PLoS ONE 5:e9490. doi: 10.1371/journal.pone.0009490

R Core Team (2015). R: A Language and Environment for Statistical Computing. Vienna: R Foundation for Statistical Computing. Retrieved from: https://www. R-project.org/.

Ribera, M. A., Gomez Garreta, A., Gallardo, T., Cormaci, M., Furnari, G., and Giaccone, G. (1992). Check-list of Mediterranean Seaweeds. I. Fucophyceae (Warming, 1884). Bot. Mar. 35, 109-130. doi: 10.1515/botm.1992.35.2.109

Schloss, P. D., Westcott, S. L., Ryabin, T., Hall, J. R., Hartmann, M., Hollister, E. B., et al. (2009). Introducing mothur: open-source, platformindependent, community-supported software for describing and comparing microbial communities. Appl. Environ. Microbiol. 75, 7537-7541. doi: 10.1128/AEM.01541-09

Serio, D., Alongi, G., Catra, M., Cormaci, M., and Furnari, G. (2006). Changes in the benthic algal flora of Linosa Island (Straits of Sicily, Mediterranean Sea). Bot. Mar. 49, 135-144. doi: 10.1515/BOT.2006.018

Soltan, D., Verlaque, M., François Boudouresque, C., and Francour, P. (2001). Changes in macroalgal communities in the vicinity of a Mediterranean sewage outfall after the setting up of a treatment plant. Mar. Pollut. Bull. 42, 59-70. doi: 10.1016/S0025-326X(00)00116-8

Staufenberger, T., Thiel, V., Wiese, J., and Imhoff, J. F. (2008). Phylogenetic analysis of bacteria associated with Laminaria saccharina. FEMS Microbiol. Ecol. 64, 65-77. doi: 10.1111/j.1574-6941.2008.00445.x

Strain, E. M. A., van Belzen, J., van Dalen, J., Bouma, T. J., and Airoldi, L. (2015). Management of local stressors can improve the resilience of marine canopy algae to global stressors. PLoS ONE 10:e0120837. doi: 10.1371/journal.pone.0120837
Strain, E. M., Thomson, R. J., Micheli, F., Mancuso, F. P., and Airoldi, L. (2014) Identifying the interacting roles of stressors in driving the global loss of canopyforming to mat-forming algae in marine ecosystems. Glob Chang Biol 20, 3300-3312. doi: 10.1111/gcb.12619

Stratil, S. B., Neulinger, S. C., Knecht, H., Friedrichs, A. K., and Wahl, M. (2013). Temperature-driven shifts in the epibiotic bacterial community composition of the brown macroalga Fucus vesiculosus. Microbiologyopen 2, 338-349. doi: $10.1002 / \mathrm{mbo} 3.79$

Thibaut, T., Blanfuné, A., Boudouresque, C. F., and Verlaque, M. (2015). Decline and local extinction of Fucales in the French Riviera: the harbinger of future extinctions? Mediterr. Mar. Sci. 16, 206-224. doi: 10.12681/mms.1032

Thibaut, T., Pinedo, S., Torras, X., and Ballesteros, E. (2005). Long-term decline of the populations of Fucales (Cystoseira spp. and Sargassum spp.) in the Alb??res coast (France, North-western Mediterranean). Mar. Pollut. Bull. 50, 1472-1489. doi: 10.1016/j.marpolbul.2005. 06.014

Wada, S., Aoki, M. N., Tsuchiya, Y., Sato, T., Shinagawa, H., and Hama, T. (2007). Quantitative and qualitative analyses of dissolved organic matter released from Ecklonia cava Kjellman, in Oura Bay, Shimoda, Izu Peninsula, Japan. J. Exp. Mar. Bio. Ecol. 349, 344-358. doi: 10.1016/j.jembe.2007. 05.024

Wahl, M., Goecke, F., Labes, A., Dobretsov, S., and Weinberger, F. (2012). The second skin: ecological role of epibiotic biofilms on marine organisms. Front. Microbiol. 3:292. doi: 10.3389/fmicb.2012. 00292

Wang, Q., Garrity, G. M., Tiedje, J. M., and Cole, J. R. (2007). Naive Bayesian Classifier for Rapid Assignment of rRNA Sequences into the New Bacterial Taxonomy. Appl. Environ. Microbiol. 73, 5261-5267. doi: 10.1128/AEM.0006207

Zozaya-Valdes, E., Egan, S., and Thomas, T. (2015). A comprehensive analysis of the microbial communities of healthy and diseased marine macroalgae and the detection of known and potential bacterial pathogens. Front. Microbiol. 6:146. doi: 10.3389/fmicb.2015.00146

Zwart, G., Hiorns, W. D., Methé, B. A., van Agterveld, M. P., Huismans, R., Nold, S. C., et al. (1998). Nearly identical 16S rRNA sequences recovered from lakes in North America and Europe indicate the existence of clades of globally distributed freshwater bacteria. Syst. Appl. Microbiol. 21, 546-556. doi: 10.1016/S0723-2020(98)80067-2

Conflict of Interest Statement: The authors declare that the research was conducted in the absence of any commercial or financial relationships that could be construed as a potential conflict of interest.

Copyright (c) 2016 Mancuso, D'Hondt, Willems, Airoldi and De Clerck. This is an open-access article distributed under the terms of the Creative Commons Attribution License (CC BY). The use, distribution or reproduction in other forums is permitted, provided the original author(s) or licensor are credited and that the original publication in this journal is cited, in accordance with accepted academic practice. No use, distribution or reproduction is permitted which does not comply with these terms. 